\title{
Impact of Sustainable Supply Chain Management Practices on Organizational Performance in Ghana
}

\author{
Isaiah Agbenu Akanbi Adegokel ${ }^{1, *} \mid$ Mingbao Cheng ${ }^{1} \mid$ Pearl Abredu² \\ Grace Chikomborero Ndafira ${ }^{1} \mid$ Priscilla Achiaa Amoateng ${ }^{1}$ | Lilian Owusu-Gyan ${ }^{1}$ \\ ${ }^{1}$ School of Business, Nanjing University of Information Science and Technology, Nanjing, China \\ ${ }^{2}$ School of Management, Jiangsu University, Zhenjiang, China \\ *Corresponding author: adegoke305@gmail.com
}

Received 27 September 2021; Revised 20 October 2021; Accepted 21 October 2021

\begin{abstract}
The study explores the impact of ecological supply chain management practices such as Green Supply Chain, environmental and operational management practices of organizational performance in Ghana. The organizational performance was measured based upon three parameters constituting Sustainable Environmental Performance (SENP), Sustainable Economic Performance (SECP), and Competitiveness (COMP). Exogenous factors included the constructs of Sustainable Supply Chain Management (SSCM) practices and the single-item construct voluntary adoption of SSCM practices, while endogenous variables included the three aspects of firm performance. The relationship between sustainable management practices and organizational performance was ascertained using Structural Equation Modeling. A few significant results are presented as follows; (1) Environmental Management Practices (EMP) results in enhanced Sustainable Environmental Performance (SENP) and Sustainable Economic Performance (SECP); (2) Organizational Performance has a strong correlation with SECP and COMP; (3) SECP has a substantial and favorable relationship with both competitiveness and sustainable environmental performance, as well as sustainable economic performance. The positive relationship between SSCM practices and firm performance demonstrates that continual sustainable management principles eventually improve community capacity. This ultimately results in an organization's competitiveness. Additionally, the managerial implications of the results are addressed.
\end{abstract}

Keywords: Sustainability; supply chain management practices; organizational performance; structural equation modeling

\section{Introduction}

The sustainability of today's companies is becoming more critical due to environmental degradation and human rights violations (Gladwin et al., 1995). Recent developments in the business environment show that pursuing economic goals alone may not be a viable long-term strategy for a company's long-term sustainability and profitability if the company's actions result in irreversible damage to the ecosystem and failure to ensure employee safety, security, minimum wage, healthcare, and better working conditions. Literature reports many studies on Green Supply 
Chain Management (GSCM) that aim to define the structures of GSCM practices and their impact on the economic and environmental performance of organizations (e.g., Zhu \& Sarkis, 2004; Darnall et al., 2008; Rao \& Holt, 2005). There is just a few theoretical research on Sustainable Supply Chain Management (SSCM) in the Supply Chain Management SCM literature (Linton et al., 2007; Vachon \& Mao, 2008). Early studies have failed to capture all the essential aspects of SSCM. In Pullman et al. (2009) study, the effects of social and environmental sustainability efforts on a company's performance were examined. SSCM procedures were outlined by Marshall et al. (2015) as those that include social and environmental considerations, using Irish businesses as specific case scenarios.

Additionally, organizations' sustainability of expansion is increasingly being questioned by the global society through the media and non-governmental organizations (NGOs) (Zhu \& Sarkis, 2004). Porter and Kramer (2006) stated that businesses must increasingly go outside their operations to satisfy the sustainability requirements of their customers. Firms with a vision are already working to make their supply chains more sustainable. The industry is becoming more conscious of the problems in modern supply chains. Numerous industrial companies now produce waste and pollution, jeopardizing the planet's existence. These obvious challenges and requirements have compelled companies to assess their activities' environmental impact. As the world's population increases and resource availability decreases, businesses see the need to rethink supply networks (Carter \& Jennings, 2002). Companies must present an image of environmental stewardship via their products, processes, systems, technology, and business practices (Vachon \& Klassen, 2006).

Considering recent changes in the global economic climate, businesses should consider rebuilding and restructuring to improve their strategy for maintaining company and profitability while staying competitive. Gupta and Palsule-Desai (2011) outlined the conceptual underpinnings of SSCM in Ghana. Social sustainability was not included in Mitra and Datta's (2014) empirical SSCM findings. Stakeholder pressure makes it harder for supply chain managers to adopt sustainable practices. Ensuring a sustainable supply chain includes using recyclable packaging, returning old products to manufacturers, and properly disposing of garbage. However, some of the most critical obstacles to adopting sustainable practices are related to issues like price competitiveness and responsiveness. Despite Europe and Asia's different views on corporate social responsibility and sustainability, Mol and Carter (2006) claim Asia values sustainability. Zailani $e t$ al. (2012) studied Malaysian sustainable supply chain management drivers. However, Eltayeb and Zailani (2014) examined how certified manufacturing businesses in Ghana adopt a green supply chain. This study is interested in establishing how Ghanaian companies are involved in the sustainable supply chain. This article will examine sustainable supply chain practices inside a business and their connection to the supply chain's performance. This paper is structured into five parts. This article begins with an introduction section that gives context for the research subject and the study's shortcomings. A review of sustainable supply chain strategies and performance is provided in Section 2. On the other hand, Section 3 describes the methodology, while Section 4 shows the study's findings. Section 5 concludes the paper's objective by discussing the results, implications, and future study directions.

\section{Literature review}

\subsection{Sustainable Supply Chain Management (SSCM)}

Sustainability refers to adhering to the triple bottom line of social, environmental, and economic obligations. Sustainability and SCM have long been contentious issues (Wang et al., 2018). Several writers have emphasized on different aspects of sustainability and SCM. Lambert and Enz (2017) describe SCM as integrating critical business operations that deliver multiple stakeholders' information, goods and services. They define it as a systematic, well-planned integration of traditional business operations and strategies across business divisions in a company's supply chain, with the primary goal of enhancing the outputs of that great organization and its supply chain. 
Stock and Boyer (2009) described it as the process of managing affiliated organizations and business divisions inside a company. These systems enable the movement of goods and services from the main to secondary sources. From the definitions, SCM is built on product and service movement, coordination of supply chain players, and information exchange. According to Ahi and Searcy (2013), SCM has the following key characteristics: flow, coordination, stakeholder, connection, value, efficiency, and performance. Academics are struggling to reconcile sustainability's triple bottom line with SCM's fundamental characteristics.

Pagell and Gobeli (2009) created the term SSCM in the business environment. SCM's fundamental components must be utilized to minimize environmental and social impacts. To accomplish this goal, SSCM must include ecological and social evaluations. It is the planned coordination of critical cross-organizational business operations to allow the company and its supply chains to achieve long-term financial outcomes. The study highlights the need to address environmental and social aspects of sustainability in supply chain operations. They help businesses improve internal processes (Wang et al., 2018).

\subsection{Green Supply Chain Management (GSCM)}

Researchers and practitioners appreciate the need to investigate the concept of a green supply chain. Eco-friendly management has been studied extensively by numerous researchers (Bowen $e t$ al., 2001). Previous research focused on monitoring its partners' compliance with environmental laws to prevent and minimize negative consequences (Viscusi, 1983). Green activities have been deemed unprofitable in this research stream, and the emphasis has moved to mitigate the damaging effects of a company's operations. GSCM adoption offers a competitive advantage and may enhance organizational performance (Atasu et al., 2008; Juma et al., 2021). Numerous studies as mentioned above have shown the value of proactive GSCM methods, including early supplier involvement. Green management may help companies achieve lean management, which improves performance (Kainuma \& Tawara, 2006). GSCM involves valuation of the environmental performance of the suppliers, so as the environmental impact of their goods can be minimized (Mahmoudi et al., 2021). Suppliers must be engaged in GSCM accomplishment to achieve sustainable integration. Also, research shows that resource reconfiguration is required for GSCM success (Dangelico et al., 2017). GSCM actions have been quantified using internal environmental management (IEM), Green Purchasing, and Eco Design. This research utilized green buying, Ecodesign, and reuse, and recycling to evaluate investment recovery. We emphasize two GSCM factors: environmental design and recycling (Spangenberg et al., 2010). Early in the product's life cycle, ecodesign is included, followed by reuse and recycling.

\subsection{Green Growth and Green Innovation}

Sustainable supplier selection has been a hot subject of discussion among academics over the past few decades. It manifests itself in a variety of ways. Indeed, it creates room to facilitate prudent supplier decisions and selections. The company must set criteria for supplier selection (Toloo \& Nalchigar, 2011). Mani et al. (2014) identified green suppliers using fuzzy set theory. A case study was given to demonstrate the method's feasibility. They utilized AHP to locate the most qualified vendor. This was suitable for usage in cars and cement industries, coupled with manufacturing firms. Trapp and Sarkis (2016) further recommended the optimization of supplier sourcing. Their approach makes use of novel integer programming techniques using an integrated approach (Luthra et al., 2017). AHP and VIKOR methods were used to identify the leading supplier utilizing Delivery Schedule Adherence (DSA) to identify environmentally friendly suppliers. They repaired the Differential Evolution (DE) algorithm by exploiting the Data Envelopment Analysis (DEA) weaknesses. DEMATEL algorithms were adopted to locate a sustainable supplier. They believe that a simple set reduces risk. Then solar air conditioners became popular. Since the 1970s, sustainable supplier selection has been researched. Identifying sustainable suppliers via the use of ANP and VIKOR. Sustainability in supplier selection is not a novel concept. Before selecting a 
supplier, a business must ascertain its requirements (Toloo \& Nalchigar, 2011). Jauhar and Pant (2017) enhanced Data Envelopment Analysis (DEA) via the usage of DE. They compare DEMATEL pairings of manufacturing firms. This is increasing our understanding of ecologically responsible development and green innovation (Albort-Morant et al., 2016). Recently, academics examined the link between professional environmental efforts and competitive success (Guoyou $e t$ al., 2013). Consumer-driven green innovation is motivated by environmental sustainability (Albino et al., 2009). Therefore, businesses produce ecologically friendly products (Dangelico \& Pujari, 2010). Businesses should invest in environmentally friendly technologies and research green innovation to enhance their environmental practices and effectiveness (Galdeano-Gomez et al., 2013). Economists believe that economic advancements may assist companies in gaining a competitive advantage. Cuerva et al. (2014) argued that green innovation is inextricably linked to environmental and quality management systems. Green innovation (GI) requires environmental regulations and legislation and market pressure (De Medeiros et al., 2014; Shahzad et al., 2020). The eco-efficiency and sustainability of green technologies influence their performance (Chang, 2016; Lopes et al., 2017). Environmental stewardship and sustainability are becoming more important in GI. Despite the above numerous models adopted for the study, this study sought to investigate the same phenomenon using SEM to corroborate or disproof whether the same happenings occur within the Ghanaian setting.

\subsection{SSCM Practices}

To help operationalize the SSCM idea, knowledge of essential activities or practices linked to sustainability and SCM is required. Academics have also researched and emphasized sustainable distribution, packaging, and reverse logistics (Pagell \& Wu, 2009). For Beske et al. (2014), proactive risk management and strategic direction are required. Sustainable manufacturing, design, distribution, and investment recovery were the focus of Esfahbodi et al. (2016). As shown before, academics' SSCM methods are heavily influenced by their research goals. This has helped SSCM practices flow. This study presents SSCM via the perspective of three key SCM components (2009). Stock and Boyer (2009) define the material flow, supplier cooperation, coordination, and information sharing. It incorporates sustainability into the components of purchasing, supplier cooperation, and information exchange (Weeratunge \& Herath, 2017). The SSCM core was modified for this research (Stock \& Boyer, 2009). Green et al. (2012) advise evaluating the impact of SSCM on performance. Overall, SSCM effect on organizational performance is more helpful. These included green information exchange, supplier partnerships, and sustainable buying. A summary of the study's SSCM components.

\subsection{Environmentally Sustainable Management Practices and Organizational Performance}

Environmental Management Practices (EMP) include implementing ecologically responsible systems for raw material procurement, clean manufacturing, eco-friendly product design and distribution, and so on (Zhu et al., 2007). In contrast, Environmental Performance (EPR) is quantified by reducing toxic material discharge, the cost of effluent treatment, and so on. Established via their study findings that the implementation of EMP increases EPR. Pullman et al. (2009) presented environmental sustainability strategies in protecting facility resources and land management result in improved EPR. Vachon and Mao (2008) demonstrate a positive connection between EPR, EMP, and the robustness of the supply chain.

Darnall et al. (2008) claim that companies using EMS are more likely to adopt green supply chain management (GSCM). This increases environmental sustainability and, therefore, EPR. According to Melnyk et al. (2003), companies with established and accredited environmental management systems have a higher EPR than those without. Yang et al. (2011) found an EMP-EPR positive correlation. Sustainable packaging (Zailani et al., 2012) and sustainable buying (Laosirihongthong et al., 2013), increases EPR. Klassen and Whybark (1999) show that implementing pollution control technology enhances EPR. The research supports the following theory: 
H1a: Environmental performance is favourably correlated with sustainable environmental management practices of Ghanaian Manufacturers.

Operations performance (OPR) is a word that refers to an organization's enhanced operational efficiency, which is often expressed in terms of cost savings, decreased energy use, and improved logistical efficiency. According to Rao and Holt (2005), adopting EMP leads to cost reductions, efficiency gains, and higher output. Klassen and Whybark (1999) show how incorporating environmental protection technologies improves a manufacturing organization's performance. According to Melnyk et al. (2003), having a formal or certified EMS is associated with better performance in terms of cost savings, quality, etc. González-Benito et al. (2005) demonstrates that using EMP improves operational performance, especially in logistics. However, as Pullman et al. (2009) explain, EMP has no apparent relationship with quality or cost performance. However, Zailani et al. (2012) show that environmental buying improves OPR. Existing literature demonstrates a generally strong connection between EMP and OPR. Based on this observation, the following hypothesis is made:

H1b: Environmentally responsible management strategies have a favourable correlation with the operational success of Ghanaian Manufacturers.

\subsection{Operational Practices and Organizational Performance}

Operational practices include using operations management methods to increase efficiency, decrease inventory, and eliminate waste across the value chain. As previously stated, operational performance refers to the degree to which an organization's performance improves due to cost savings and increased efficiency due to the operational practices implemented. According to the above reasoning, operational procedures should logically increase both operational performance and competitive advantage. Kaynak (2003) claimed that improved processing and supplier quality management techniques result in improved quality management and inventory management performance. Advanced operations management systems have a statistically significant beneficial connection with mass and lean operational performance (González-Benito et al., 2005). When it comes to operational procedures like supply chain integration and supply chain coordination, Kannan and Tan (2005) revealed these parameters assist a company to be more competitive in the long run.

Literature (Yang et al., 2011; 2010) suggests that lean manufacturing enhances market and financial performance. Supply chain strategies and continuous improvement techniques like Just in Time and Total quality management enhance a firm's cost, quality, and delivery competitiveness. According to Li et al. (2006), SCM processes that contain all essential components significantly improve an organization's performance and competitive advantage. Thus, two hypotheses can be advanced:

H2a: Operational practices and performance are favorably correlated among Ghanaian Manufacturers.

H2b: Operational practices have a favorable positive correlation with a firm's competitiveness among Ghanaian Manufacturers.

\subsection{Relationship Between Operational and Environmental Performance and Organizational Competitiveness}

Although the connection between environmental performance and competition seems unclear, it favors a positive outcome. Klassen and McLaughlin (1996) demonstrate that businesses that perform better environmentally are expected to do better financially. According to Pullman et al. (2009), there is a significant positive connection between environmental and quality performance, but not between environmental and cost performance. Rao and Holt (2005) claim that better environmental performance leads to better commercial performance and better competitiveness. A strong positive relationship between environmental performance improvement and costcompetitive advantage is shown by López-Gamero et al. (2009). Yang et al. (2011) links 
environmental performance to market and financial success. Considering the above, we hypothesize:

H3: Environmental performance has a favourable correlation with a Ghanaian manufacturing firm's competitiveness.

The competitiveness of an organization can be improved through an increase in economic performance in areas such as delivery, responsiveness to customer needs, reduction in cost of production, increase in products quality and many more. Numerous researches have demonstrated these assertions (Kaynak, 2003; Kannan \& Tan, 2005). According to Zain and Kassim (2012), continual development results in increased company competitiveness, which significantly impacts business performance. According to Ahmed et al. (2014), developing a company's economics skills improve a firm's performance. As a result, the following hypothesis is made:

H4: There is a positive association existing between Economic performance and Manufacturing firms' competitiveness.

\subsection{Eco-design and Organizational Performance}

Eco-design is the process of developing and using technical innovations to minimize damage to the environment throughout the supply chain (Zhu et al., 2008). This design approach impacts the whole life cycle of goods. Environmental problems must be addressed early in the design process, such as during planning and conceptual design phases. The design level accounts for almost $80 \%$ of all product-related environmental impacts (Spangenberg et al., 2010). Eco-design, therefore, must be dealt with comprehensively, from the beginning (buying) to the end (distribution to consumers). To develop environmentally-friendly goods, the manufacturing firm must collaborate with its suppliers by taking market requirements or rivals' strategies into account (Koufteros et al., 2007). Suppliers may stay current on market developments via knowledge-sharing procedures to share information with buyers, strengthening coordination (Cousins et al., 2006). It also improves supply chain performance by decreasing partner coordination time and boosting market-focused goods (e.g., Eco-design).

\subsection{GSCM and Organizational Performance}

GSCM and supply chain performance has been studied from different perspectives (Schaltegger \& Burritt, 2014). Usually, corporate performance has been characterized by the quality of the company's financial, operational, and product performances (Tsoulfas \& Pappis, 2008). Environmental performance has been essential, but environmental concerns are also growing (Wu, et al., 2015). Environmentalists have been seeking to promote environmentally conscious buying habits among customers in recent years. The following are examples of environmental performance measures: carbon monoxide emission, wastewater water, and solid waste (Zhu \& Sarkis, 2004). Berry and Rondinelli (1998) have shown that practical environmental management policies successfully prevent hazardous behaviours. Prior studies have shown positive results from GSCM implementation; our research follows in their footsteps by minimizing negative consequences and eco-friendly design (Zhu et al., 2008). Those two elements may cover the whole of the manufacturing process. A supply chain may work together to achieve success in green supply chains, in which businesses can detect issues that damage the environment. This research hypothesizes that.

H5a: There is a positive effect of Eco-design on Ghanaian Manufacturing firms' environmental performance.

It is usually the most crucial element for companies to adopt new strategies. GSCM is a relatively new approach for companies; hence, we must demonstrate the connection between environmental management and economic success (Rao \& Holt, 2005). It is believed that bettering the environment may help businesses manage risk and gain in innovation and profit (Tsoulfas \& Pappis, 2008; Berry \& Rondinelli, 1998). Another benefit of publicizing the firm's green management policies is that it improves its reputation and profitability or financial gains. Studies 
have shown that businesses benefit from improved profit margins by introducing new standards using GSCM (Hart \& Ahuja, 1996). Based on these findings, a tentative theory is posited.

H5b: GSCM improves an organization's operational performance.

The study was based on the premise that informed a research model and, thus, a specific methodology was created. This gives entrepreneurs in Ghana the ability to conclude, evaluate results, and make strategic managerial inferences about sustainable management practices. The following diagram describes the concept shown in Figure 1. In the picture below, you can see the suggested model designed for this study. The model considers three SSCM practice components independent variables and three SSCM performance construct dependent variables. The picture below demonstrates how this supposed connection is represented. This was already stated in the hypothesis section. A staff count was utilized to control the influence of a company's size on SSCM processes and performance metrics.

\section{Research methodology}

\subsection{Demographics}

The study employed an explanatory research design to examine the significant connection between the research variables. The demographic characteristics of this research was manufacturers and suppliers in Ghana's capital city of Accra. Two hundred manufacturing businesses were randomly selected for the study to ensure that all responders had an equal opportunity. Simple random selection ensured that all responders from different companies had an equal chance of being chosen. Table 1 shows the respondents' demographics.

\subsection{Research instrument}

We gathered data using a questionnaire survey technique, which is very common in business research. We structured the questions for data collection and analyzed them using AMOS (v22) software to establish the inferential connection between the variables. The questionnaire utilized a 5-point Likert scale to express the respondent's intensity and emotions to the relationship that exist between sustainable supply chain management practices and supply chain performance. The Likert scale ranged from $(1=$ "strongly agree") to $(5=$ "strongly disagree") was adopted for the data collection on the construct measured. We requested three experienced researchers to evaluate the

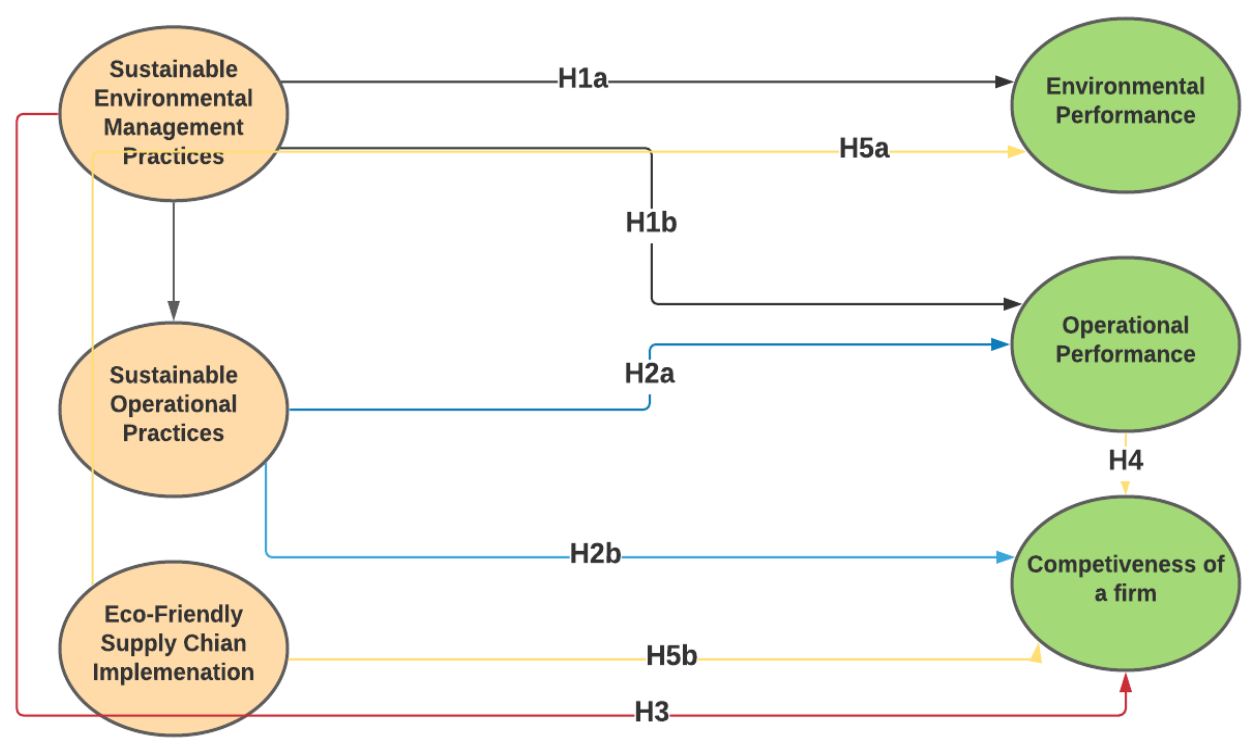

Figure 1. The conceptual framework of the study 
Table 1. Respondents' demographics

\begin{tabular}{|c|c|c|c|}
\hline Variables and Sub-scale & Frequency (\%) & Variables and Sub-scale & Frequency (\%) \\
\hline 1. GENDER & & 5. TYPE OF INDUSTRY & \\
\hline Male & $127(63.5)$ & Food & $33(16.5)$ \\
\hline Female & $73(36.5)$ & Mining & $11(5.5)$ \\
\hline E. EDUCATION & & Service & $41(20.5)$ \\
\hline Undergraduate & $73(36.5)$ & Agriculture & $57(28)$ \\
\hline Graduate & $51(25.5)$ & Cosmetics & $14(7)$ \\
\hline Postgraduate & $66(33)$ & Consultancy & $10(5)$ \\
\hline Doctorate & $10(5)$ & Media & $4(2)$ \\
\hline EXPERIENCE & & Fabrics & $4(2)$ \\
\hline <5 years & $93(45.5)$ & Shipping & $4(2)$ \\
\hline 6-10 years & $40(20)$ & $<5$ years & $80(40)$ \\
\hline $11-15$ years & $18(9)$ & $6-10$ years & $63(31.5)$ \\
\hline $16-20$ years & $13(6.5)$ & $11-15$ years & $25(12.5)$ \\
\hline$>20$ years & $24(12)$ & $16-20$ years & $22(11)$ \\
\hline POSITION & & $>20$ years & $10(5)$ \\
\hline Production officer & $36(18)$ & $<100$ & $65(32.5)$ \\
\hline Purchasing officer & $57(28.5)$ & $101-500$ & $46(23)$ \\
\hline Assistant Manager & $59(29.5)$ & 7. NUMBER OF EMPLOYEES & $43(21.5)$ \\
\hline Senior Manager & $29(14.5)$ & $501-1000$ & $26(13)$ \\
\hline Managing Director & $9(4.5)$ & $10001-2000$ & $20(10)$ \\
\hline CEO & $10(5)$ & $>2000$ & \\
\hline & & & \\
\hline & & & \\
\hline
\end{tabular}

survey questions in the first round for appropriateness and ambiguity. The survey questions were modified in response to the comments to ensure that they were tailored and pragmatic. Four SCM practitioners were then given the survey questionnaires. They double-checked the questionnaire's Items dimension for relevance to the research objectives and hypothesis that governed the study. Testing yielded survey items with high content validity.

For SSCM, three aspects were chosen, namely Environmental, operational, and eco-friendly management methods. The online survey data was verified for accuracy. Next, the data was coded and entered IBM SPSS (v25) and then into AMOS (v22). The first portion was assessed using frequency and percentages. The Structural Equation Model was used (SEM). Third, SEM was used to quantify the study hypotheses, particularly Explanatory and Confirmatory Factor Analysis (CFA). Variance Inflator Factors (VIF), NFI, GFI, RMSEA, X2/df, CFI, and AGFI was used to assess model fitness.

\section{Results and discussion}

An analysis of the relationship between sustainable supply chain management and company success was conducted (SEM). Exogenous and endogenous variables are correlated using complicated series and statistical estimations.

Our structural model's construct validity was assessed utilizing the CR and AVE (Fornell \& Lacker, 1981). Convergent validity requires an AVE of 0.50 (Chin \& Yao, 2014). The square root of each latent construct's AVE should exceed the correlation coefficients between them (Fornell \& Lacker, 1981). Table 2 shows that the AVE for each latent construct exceeds the intercorrelations. Difficulty in discriminating Also tested for dependability was Cronbach's alpha and Composite reliability. Composite reliability of 0.60 and Cronbach's reliability of 0.70 (Devon et al., 2007) was considered satisfactory. This criterion was not met, as seen in Table 3. So, conclusions made from the results of the study are reliable.

Table 4 presents the structural model's findings. All standardized factor loadings in Table 2 have $\mathrm{t}$-values greater than $1.96\left(\mathrm{t}_{\text {cal }}>\mathrm{t}_{\text {critical }}\right)$. Chin (1998) proposed factor loadings for assessing the relationship between independent and dependent variables (Field, 2009; Hair et al., 2006). As presented in Table 4, the Standardized Factor Loadings are over the limit for such analyses. 
Table 2. Correlation Matrix

\begin{tabular}{|l|c|c|c|c|c|c|c|c|c|c|}
\hline Variable & Mean & $\begin{array}{c}\text { Std. } \\
\text { Dev. }\end{array}$ & $\mathbf{1}$ & $\mathbf{2}$ & $\mathbf{3}$ & $\mathbf{4}$ & $\mathbf{5}$ & $\mathbf{6}$ & $\mathbf{7}$ & $\mathbf{8}$ \\
\hline EMP & 45.43 & 6.63 & $\mathbf{0 . 9 0 2}$ & & & & & & & \\
\hline OP & 58.21 & 5.79 & $0.718^{* *}$ & $\mathbf{0 . 9 0 7}$ & & & & & & \\
\hline ECP & 57.23 & 5.78 & $0.657^{* *}$ & $0.650^{* *}$ & $\mathbf{0 . 9 0 3}$ & & & & & \\
\hline SECP & 61.13 & 6.66 & $0.655^{* *}$ & $0.344^{* *}$ & $0.572^{* *}$ & $\mathbf{0 . 9 0 4}$ & & & & \\
\hline SENP & 69.23 & 5.09 & $0.604^{* *}$ & $0.187^{* *}$ & $0.174^{* *}$ & $0.356^{* *}$ & $\mathbf{0 . 9 0 1}$ & & & \\
\hline COMP & 70.12 & 5.89 & $0.631^{* *}$ & $0.651^{* *}$ & $0.123^{* *}$ & $0.241^{* *}$ & $\mathbf{0 . 5 6 1 * *}$ & & $\mathbf{0 . 8 5 8}$ & \\
\hline
\end{tabular}

*** Correlation is statistically significant at the 0.01 level (2- tailed); diagonals: AVEs's square root

Table 3. Fitting Indices

\begin{tabular}{|l|l|l|l|l|l|l|l|}
\hline \multirow{2}{*}{ Fitting Index } & \multicolumn{7}{|c|}{ Fitting Parameters } \\
\cline { 2 - 8 } & $\mathbf{x} / \mathbf{d f}$ & RMSEA & CFI & TLI & GFI & NFI & SRMR \\
\hline Fitting Indices & 1.532 & 0.0521 & 0.929 & 0.952 & 0.944 & 0.948 & 0.0423 \\
\hline
\end{tabular}

Table 4. Results of the structural model

\begin{tabular}{|c|c|c|c|c|c|c|c|}
\hline $\begin{array}{l}\text { Latent } \\
\text { Variable }\end{array}$ & Items & $\begin{array}{l}\text { Standardized } \\
\text { loading }\end{array}$ & $\begin{array}{c}\mathrm{t}- \\
\text { value }\end{array}$ & $\begin{array}{c}\mathrm{p}- \\
\text { value }\end{array}$ & AVE & CR & $\begin{array}{c}\text { Cronbach's } \\
\text { Alpha }\end{array}$ \\
\hline \multirow{7}{*}{ EMP } & EMP1 & 0.81 & 8.53 & $* * *$ & \multirow{7}{*}{0.814} & \multirow{7}{*}{0.909} & \multirow{7}{*}{0.813} \\
\hline & EMP2 & 0.85 & 8.55 & $* * *$ & & & \\
\hline & EMP3 & 0.84 & 8.51 & $* * *$ & & & \\
\hline & EMP4 & 0.87 & $\mathrm{a}$ & $\mathrm{a}$ & & & \\
\hline & EMP5 & 0.86 & 7.98 & $* * *$ & & & \\
\hline & EMP6 & 0.83 & 8.35 & $* * *$ & & & \\
\hline & EMP7 & 0.88 & 8.92 & $* * *$ & & & \\
\hline \multirow{3}{*}{ OP } & OP8 & 0.81 & 7.96 & $* * *$ & \multirow{3}{*}{0.823} & \multirow{3}{*}{0.911} & \multirow{3}{*}{0.823} \\
\hline & OP9 & 0.83 & $\mathrm{a}$ & $\mathrm{a}$ & & & \\
\hline & OP10 & 0.81 & 8.48 & $* * *$ & & & \\
\hline \multirow{3}{*}{ ECP } & ECP11 & 0.89 & 7.98 & $* * *$ & \multirow{3}{*}{0.815} & \multirow{3}{*}{0.935} & \multirow{3}{*}{0.829} \\
\hline & ECP12 & 0.86 & $\mathrm{a}$ & $\mathrm{a}$ & & & \\
\hline & ECP13 & 0.82 & 7.69 & $* * *$ & & & \\
\hline \multirow{5}{*}{ SECP } & SECP14 & 0.89 & 7.98 & $* * *$ & \multirow{5}{*}{0.817} & \multirow{5}{*}{0.922} & \multirow{5}{*}{0.918} \\
\hline & SECP15 & 0.91 & 8.09 & $* * *$ & & & \\
\hline & SECP16 & 0.81 & $\mathrm{a}$ & $\mathrm{a}$ & & & \\
\hline & SECP17 & 0.84 & 7.19 & *** & & & \\
\hline & SECP18 & 0.85 & 7.98 & $* * *$ & & & \\
\hline \multirow{5}{*}{ SENP } & SENP19 & 0.85 & 7.36 & $* * *$ & \multirow{5}{*}{0.812} & \multirow{5}{*}{0.812} & \multirow{5}{*}{0.816} \\
\hline & SENP20 & 0.78 & 7.28 & $* * *$ & & & \\
\hline & SENP21 & 0.84 & $\mathrm{a}$ & $\mathrm{a}$ & & & \\
\hline & SENP22 & 0.87 & 7.88 & $* * *$ & & & \\
\hline & SENP23 & 0.83 & 7.28 & $* * *$ & & & \\
\hline \multirow{5}{*}{ COMP } & COMP24 & 0.87 & 7.44 & $* * *$ & \multirow{5}{*}{0.736} & \multirow{5}{*}{0.911} & \multirow{5}{*}{0.796} \\
\hline & COMP25 & 0.88 & 7.78 & $* * *$ & & & \\
\hline & COMP26 & 0.88 & $\mathrm{a}$ & $\mathrm{a}$ & & & \\
\hline & COMP27 & 0.81 & 7.82 & $* * *$ & & & \\
\hline & COMP28 & 0.91 & 7.71 & $* * *$ & & & \\
\hline
\end{tabular}

$A V E=\sum \frac{K^{2}}{n} ; C R=\frac{\left(\sum K\right)^{2}}{\left(\sum K\right)^{2}+\sum\left(1-K^{2}\right)}$; where $K$ denotes the factor loadings of all items in a build and $n$ denotes the number of things in a construct; ${ }^{* * *} \mathrm{p}$-value $<0.001$ (2-tailed); a: Unitized parameter.

Table 4 briefly describes the degree of relationship that exists between all the constructs under investigation.

The model's "fitness" to the data is estimated to determine whether was deemed appropriate to measure the relationship that exist between the dependent and independent variables. Model fit evaluation is used to verify a theoretical model via parameter fitting (Benah \& Li, 2020; Kir et al., 2021). The model's fitness was assessed using the RMSEA, CFI, TLI, GFI, NFI, and Standardized Root Mean Square Residual indices (SRMR). Kline (2005) recommends providing model 2, 
RMSEA, CFI, and SRMR as minimal model fit indices. The research analysis revealed the model for both the individual construct and the entire study was acceptable, which validates the study's results, as shown in Table 3.

The statistical significance of the eight hypotheses was determined using structural equation modelling at a $95 \%$ confidence interval. Environmental performance, sustainable economic performance, and competitiveness are all measures of firm performance in the manufacturing sector.

Proposition 1: Environmental performance is favorably correlated with sustainable environmental management practices of Ghanaian Manufacturers (H1a). Environmentally responsible management strategies have a favorable correlation with the operational success of Ghanaian Manufacturers (H1b).

Proof of Proposition 1: Sustainable Environmental management methods and environmental performance of businesses in supply chain sectors, including food, mining, services, among others, are shown in Table 5 . As shown by the coefficient $\left(\beta_{1 \mathrm{a}}=0.86 ; \mathrm{p}<0.001\right)$, an increase in sustainable environmental practices such as addressing customer concerns about eco-friendly product distribution, along with middle-level managers always supporting the establishment of green sustainable management goals would increase environmental performance by (.86). The researchers reject the null hypothesis and hence, investigated the alternative hypothesis. Another hypothesis examined showed a link between sustainable ecological practices and the environmental performance of the Ghanaian businesses studied. The coefficient $\left(\beta_{1 \mathrm{~b}}=0.81 ; \mathrm{p}<0.001\right)$ shows that improving sustainable environmental practices enhances supply chain performance in Ghana. The findings of the study corroborate with the literature (Harms et al., 2013; Rao \& Goldsby, 2009; Zailani et al., 2012; Zhu et al., 2007).

Proposition 2: Operational practices and performance are favorably correlated among Ghanaian Manufacturers (H2a). Operational practices have a favorable positive correlation with a firm's competitiveness among Ghanaian Manufacturers (H2b).

Proof of Proposition 2: SEM was used to test the second study hypothesis. Table 5 shows a strong positive relationship between operational practices and performance. Table 5 indicates that the study's analysis accepted the hypothesis $(\beta 2 \mathrm{a}=0.87$ and $\mathrm{p}<0.001)$. For instance, the operational practices of keeping inventory under control, implementing lean production, and achieving economies of scale positively influence firms' operational performance by $87 \%$. The research showed that a $1 \%$ improvement in the operational practices increased a firm's competitiveness by $\left(\beta_{2 \mathrm{~b}}=0.87 ; \mathrm{p}<0.001\right)$. In other words, operational methods would enhance product quality, overall productivity, and competitiveness (Kaynak, 2003; Yang et al., 2010). Advanced operations management systems and mass and lean operational performance are linked and in connection with the conclusions of González-Benito et al. (2005) and, Kannan and Tan (2005).

Proposition 3: Environmental performance has a favourable correlation with a Ghanaian manufacturing firm's competitiveness (H3).

Proof of Proposition 3: Table 6 shows that environmental performance has a statistically significant beneficial impact on a firm's competitiveness. This was amply reflected in the coefficient $\left(\beta_{3}=0.85\right.$; $\mathrm{p}<0.01$ ), showing that environmental performance such as reducing air emission, water, and consumption of hazardous materials, and increase in energy save significantly influences firms' ability to engage in sustainable competitions. This signifies that the environmental performance appears to positively associate with competitiveness in creating opportunities for the firm to target new green sustainability-sensitive customers. This will allow the firms to have a competitive advantage over other firms that fail to practice sustainable environmental, operational, and ecofriendly management practices. The findings of the study corroborate with the literature (Rao \& Goldsby, 2009; Yang et al., 2011). 
Proposition 4: Economic success and manufacturing company competitiveness are positively correlated (H4).

Proof of Proposition 4: Table 5 shows a favorable correlation between economic success and business competitiveness. This was revealed in the coefficient $\left(\beta_{4}=0.86 ; \mathrm{p}<0.01\right)$, indicating that economic performance such as improved operations and supply chain performance logically improves competitiveness. This echoed the fact that a percentage increase in economic performance. Again, improvement in a company's per-share earnings and returns on investment, as well as reduction in waste discharge would increase the company's competitiveness. This finding is in line with the findings of numerous works (Kaynak, 2003; Li et al., 2006; Kannan \& Tan, 2005).

Proposition 5: Eco-friendly Sustainable Practices have a significant effect on Ghanaian Manufacturing firms' environmental performance (H5a). GSCM improves an organization's operational performance of Ghanaian Manufacturing firm's (H5b).

Proof of Proposition 5: Table 5 shows a strong positive connection between GSCM adoption and environmental implementation. Eco-friendly management techniques create a significant positive impact on companies' environmental performance. This is such that a percentage increase in GSCM would substantially improve environmental performance $\left(\beta_{5 b}=0.84 ; \mathrm{p}<0.001\right)$. The research also showed that GSCM enhances an organization's operational effectiveness. The coefficient score $\left(\beta_{5 \mathrm{~b}}=0.82, \mathrm{p}<0.001\right)$ reflected this relationship between eco-friendly practices and operational performance. This confirms the findings of Cousins et al. (2006) and Zhu et al. (2008) for H5a, and Tsoulfas and Pappis (2008) and Zhu and Sarkis (2004) for H5b.

\section{Conclusion}

The study hypothesized several relationships between SSCM practices (for example, environmental management, operations, and eco-friendly supply chain practices for manufacturing firms and SSCM performance measures (environmental, operations, and competitiveness). Some of the conclusions corroborate those of previous studies, while others go contrary to early findings. The results from rigorous statistical testing aid in the development of hypotheses about the numerous aspects of SSCM. The study's assumptions and subsequent confirmation strengthen the established theory of SSCM from the viewpoint of Ghanaian organizations. However, the unsupported theories have shown a new dynamism in terms of contextual variables. This demonstrates that the validity of many assumptions is conditional on the environment of the developing or established economy in which the companies were sampled and the maturity of the SSCM techniques implemented by each company. Additional research from the perspective of other emerging countries is required to substantiate these claims. The research has several drawbacks. First, the sample size of informants from various sectors is not consistent, which may tilt the study's findings to be bias toward a specific industry. Second, the firms selected represent a diverse range of industries. The maturity of SSCM processes varies significantly across various kinds of businesses, and as a result, respondents' perceptions also differ considerably across these sectors. The research attempted to generalize the results based on answers from several sectors.

Table 5. Hypothesis Testing and Decision

\begin{tabular}{|c|c|c|c|c|c|c|}
\hline Hypothesis & Relationship & $\begin{array}{c}\text { Path } \\
\text { coefficient }\end{array}$ & SE & t-value & $\begin{array}{l}\text { Sig- } \\
\text { value }\end{array}$ & $\begin{array}{c}\text { Hypothesis } \\
\text { Decision }\end{array}$ \\
\hline $\mathrm{H} 1 \mathrm{a}$ & EMP $\rightarrow$ SENP & 0.86 & 0.23 & 19.715 & $* * *$ & Fail to Reject \\
\hline $\mathrm{H} 1 \mathrm{~b}$ & $\mathrm{EMP} \rightarrow \mathrm{SECP}$ & 0.81 & 0.27 & 14.688 & $* * *$ & Fail to Reject \\
\hline $\mathrm{H} 2 \mathrm{a}$ & $\mathrm{OP} \rightarrow \mathrm{SECP}$ & 0.87 & 0.26 & 13.483 & $* * *$ & Fail to Reject \\
\hline $\mathrm{H} 2 \mathrm{~b}$ & $\mathrm{OP} \rightarrow \mathrm{COMP}$ & 0.87 & 0.29 & 16.517 & $* * *$ & Fail to Reject \\
\hline $\mathrm{H} 3$ & $\mathrm{EMP} \longrightarrow \mathrm{COMP}$ & 0.85 & 0.35 & 15.426 & $* * *$ & Fail to Reject \\
\hline $\mathrm{H} 4$ & $\mathrm{ECP} \rightarrow \mathrm{COMP}$ & 0.86 & 0.21 & 19.801 & $* * *$ & Fail to Reject \\
\hline $\mathrm{H} 5 \mathrm{a}$ & $\mathrm{ECP} \rightarrow \mathrm{SENP}$ & 0.84 & 0.26 & 18.101 & $* * *$ & Fail to Reject \\
\hline $\mathrm{H} 5 \mathrm{~b}$ & $\mathrm{ECP} \rightarrow \mathrm{SECP}$ & 0.82 & 0.31 & 15.213 & $* * *$ & Fail to Reject \\
\hline
\end{tabular}

*** Statistical significance $(p=0.05)$ 
Probably, the results would have shown a more consistent trend, if the investigation had been limited to a few distinct industries and responses gathered from solely companies that fall within the sector. Third, the present study did not examine any significant variations in respondents' perceptions of various sectors. Additionally, it did not investigate any potential substantial variations in respondents' perceptions of companies of varying employee count or yearly revenue.

\section{References}

Ahi, P. \& Searcy, C. (2013). A comparative literature analysis of definitions for green and sustainable supply chain management. Journal of Cleaner Production, 52, 329-341. https://doi.org/10.1016/j.jclepro.2013.02.018

Ahmed, M. U., Kristal, M. M., \& Pagell, M. (2014). Impact of operational and marketing capabilities on firm performance: Evidence from economic growth and downturns. International Journal of Production Economics, 154, 59-71. https://doi.org/10.1016/j.ijpe.2014.03.025

Albino, V., Balice, A., \& Dangelico, R. M. (2009). Environmental strategies and green product development: an overview on sustainability-driven companies. Business strategy and the environment, 18(2), 83-96. https://doi.org/10.1002/bse.638

Albort-Morant, G., Leal-Millán, A., \& Cepeda-Carrión, G. (2016). The antecedents of green innovation performance: A model of learning and capabilities. Journal of Business Research, 69(11), 4912-4917. https://doi.org/10.1016/j.jbusres.2016.04.052

Atasu, A., Guide Jr, V. D. R., \& Van Wassenhove, L. N. (2008). Product reuse economics in closed-loop supply chain research. Production and Operations Management, 17(5), 483-496. https://doi.org/10.3401/poms.1080.0051

Benah, S., \& Li, Y. (2020). Examining the Relationship between Lean Supplier Relationship Management (LSRM) and Firm Performance: A Study on Manufacturing Companies in Ghana. Open Journal of Business and Management, 8(6), 2423. https://doi.org/10.4236/ojbm.2020.86150

Berry, M. A., \& Rondinelli, D. A. (1998). Proactive corporate environmental management: A new industrial revolution. Academy of Management Perspectives, 12(2), 38-50. https://doi.org/10.5465/ame.1998.650515

Beske, P., Land, A., \& Seuring, S. (2014). Sustainable supply chain management practices and dynamic capabilities in the food industry: A critical analysis of the literature. International Journal of Production Economics, 152, 131-143. https://doi.org/10.1016/j.ijpe.2013.12.026

Bowen, F. E., Cousins, P. D., Lamming, R. C., \& Farukt, A. C. (2001). The role of supply management capabilities in green supply. Production and Operations Management, 10(2), 174-189. https://doi.org/10.1111/j.1937-5956.2001.tb00077.x

Carter, C. R., \& Jennings, M. M. (2002). Social responsibility and supply chain relationships. Transportation Research Part E: Logistics and Transportation Review, 38(1), 37-52. https://doi.org/10.1016/S13665545(01)00008-4

Chang, C. H. (2016). The determinants of green product innovation performance. Corporate Social Responsibility and Environmental Management, 23(2), 65-76. https://doi.org/10.1002/csr.1361

Chin, C.L., \& Yao, G. (2014). Convergent validity. In A. C. Michalos (Ed.), Encyclopedia of quality of life and well-being research (np). Dordrecht, Germany: Springer. https://doi:10.1007/978-94-007-07535

Chin, W. W. (1998). Commentary: Issues and Opinion on Structural Equation Modeling. MIS Quarterly, 22(1), vii-xvi. http://www.jstor.org/stable/249674

Cousins, P. D., Handfield, R. B., Lawson, B., \& Petersen, K. J. (2006). Creating supply chain relational capital: The impact of formal and informal socialization processes. Journal of operations management, 24(6), 851863. https://doi.org/10.1016/j.jom.2005.08.007

Cuerva, M. C., Triguero-Cano, Á., \& Córcoles, D. (2014). Drivers of green and non-green innovation: empirical evidence in Low-Tech SMEs. Journal of Cleaner Production,68, 104-113. https://doi.org/10.1016/j.jclepro.2013.10.049

Dangelico, R. M., \& Pujari, D. (2010). Mainstreaming green product innovation: Why and how companies integrate environmental sustainability. Journal of Business Ethics, 95(3), 471-486. https://doi.org/10.1007/s10551-010-0434-0

Dangelico, R. M., Pujari, D., \& Pontrandolfo, P. (2017). Green product innovation in manufacturing firms: A sustainability-oriented dynamic capability perspective. Business strategy and the Environment, 26(4), 490 506. https://doi.org/10.1002/bse.1932 
Darnall, N., Jolley, G. J., \& Handfield, R. (2008). Environmental management systems and green supply chain management: complements for sustainability?. Business Strategy and the Environment, 17(1), 30-45. https://doi.org/10.1002/bse.557

De Medeiros, J. F., Ribeiro, J. L. D., \& Cortimiglia, M. N. (2014). Success factors for environmentally sustainable product innovation: a systematic literature review. Journal of Cleaner Production, 65, 76-86. https://doi.org/10.1016/j.jclepro.2013.08.035

DeVon, H. A., Block, M. E., Moyle-Wright, P., Ernst, D. M., Hayden, S. J., Lazzara, D. J., ... \& KostasPolston, E. (2007). A psychometric toolbox for testing validity and reliability. Journal of Nursing Scholarship, 39(2), 155-164. https://doi.org/10.1111/j.1547-5069.2007.00161.x

Eltayeb, T., \& Zailani, S. (2014). Going green through green supply chain initiatives toward environmental sustainability. Operations and Supply Chain Management: an International Journal,2(2), 93-110. http://doi.org/10.31387/oscm040019

Esfahbodi, A., Zhang, Y., \& Watson, G. (2016). Sustainable supply chain management in emerging economies: Trade-offs between environmental and cost performance. International Journal of Production Economics, 181, 350-366. https://doi.org/10.1016/j.ijpe.2016.02.013

Field, A. P. (2009). Discovering Statistics Using SPSS (3 $3^{\text {rd }}$ ed.). London: Sage Publications Ltd.

Fornell, C., \& Larcker, D. F. (1981). Evaluating structural equation models with unobservable variables and measurement error. Journal of Marketing Research, 18(1), 39-50. https://doi.org/10.1177/002224378101800104

Galdeano-Gómez, E., Aznar-Sánchez, J. A., \& Pérez-Mesa, J. C. (2013). Sustainability dimensions related to agricultural-based development: the experience of 50 years of intensive farming in Almería (Spain). International Journal of Agricultural Sustainability, 11(2), 125-143. https://doi.org/10.1080/14735903.2012.704306.

Gladwin, T. N., Kennelly, J. J., \& Krause, T. S. (1995). Shifting paradigms for sustainable development: Implications for management theory and research. Academy of management Review, 20(4), 874-907. https://doi.org/10.5465/amr.1995.9512280024

González-Benito, J., \& González-Benito, Ó. (2005). Environmental proactivity and business performance: an empirical analysis. Omega, 33(1), 1-15. https://doi.org/10.1016/j.omega.2004.03.002

Green, K. W., Zelbst, P. J., Meacham, J., \& Bhadauria, V. S. (2012). Green supply chain management practices: impact on performance. Supply Chain Management, 17 (3), 290-305. https://doi.org/10.1108/13598541211227126.

Guoyou, Q., Saixing, Z., Chiming, T., Haitao, Y., \& Hailiang, Z. (2013). Stakeholders' influences on corporate green innovation strategy: a case study of manufacturing firms in China. Corporate Social Responsibility and Environmental Management, 20(1), 1-14. https://doi.org/10.1002/csr.283.

Gupta, S., \& Palsule-Desai, O. D. (2011). Sustainable supply chain management: Review and research opportunities. IIMB Management review, 23(4), 234-245. https://doi.org/10.1016/j.iimb.2011.09.002.

Hair Jr., Black, J. F., Babin, W. C., Anderson, R. E., \& Tatham, R. L. (2006). Multivariate data Analysis (6th ed.). Upper Saddle River, NJ: Pearson-Prentice Hall.

Harms, D., Hansen, E. G., \& Schaltegger, S. (2013). Strategies in sustainable supply chain management: an empirical investigation of large German companies. Corporate social responsibility and environmental management, 20(4), 205-218. https://doi.org/10.1002/csr.1293

Hart, S. L., \& Ahuja, G. (1996). Does it pay to be green? An empirical examination of the relationship between emission reduction and firm performance. Business strategy and the Environment, 5(1), 30-37. https://doi.org/10.1002/(SICI)1099-0836(199603)5:1<30::AID-BSE38>3.0.CO;2-Q

Jauhar, S. K., \& Pant, M., (2017). Integrating DEA with DE and MODE for sustainable supplier selection. Journal of Computational Science, 21, 299-306. https://doi.org/10.1016/j.jocs.2017.02.011

Juma, L., Ikram, M., Alkalha, Z., \& Alaraj, M. (2021). Factors affecting managers' intention to adopt green supply chain management practices: evidence from manufacturing firms in Jordan. Environmental Science and Pollution Research. https://doi.org/10.1007/s11356-021-16022-7

Kainuma, Y., \& Tawara, N. (2006). A multiple attribute utility theory approach to lean and green supply chain management. International Journal of Production Economics, 101(1), 99-108. https://doi.org/10.1016/j.ijpe.2005.05.010

Kannan, V. R., \& Tan, K. C. (2005). Just in time, total quality management, and supply chain management: understanding their linkages and impact on business performance. Omega, 33(2), 153-162. https://doi.org/10.1016/j.omega.2004.03.012 
Kaynak, H. (2003). The relationship between total quality management practices and their effects on firm performance. Journal of Operations Management, 21(4), 405-435. https://doi.org/10.1016/S02726963(03)00004-4

Kir, K. F., Sarpong, F. A., Dazagbyilo, Y. Y. K., \& Boukari, M. (2021). Research on the Effects of Influencing Factors of International Students on Employability: A Case Study in China. Open Journal of Business and Management, 9(4), 1942-1964. https://doi.org/10.4236/ojbm.2021.94105

Klassen, R. D., \& Whybark, D. C. (1999). Environmental management in operations: the selection of environmental technologies. Decision Sciences, 30(3), 601-631. https://doi.org/10.1111/j.15405915.1999.tb00900.x

Koufteros, X. A., Cheng, T. E., \& Lai, K. H. (2007). "Black-box" and "gray-box" supplier integration in product development: Antecedents, consequences and the moderating role of firm size. Journal of Operations Management, 25(4), 847-870. https://doi.org/10.1016/j.jom.2006.10.009

Lambert, D. M., \& Enz, M. G. (2017). Issues in supply chain management: Progress and potential. Industrial Marketing Management, 62, 1-16. https://doi.org/10.1016/j.indmarman.2016.12.002

Laosirihongthong, T., Adebanjo, D., \& Tan, K. C. (2013). Green supply chain management practices and performance. Industrial Management \& Data Systems, $113 \quad$ (8), 1088-1109. https://doi.org/10.1108/IMDS-04-2013-0164

Li, S., Ragu-Nathan, B., Ragu-Nathan, T. S., \& Rao, S. S. (2006). The impact of supply chain management practices on competitive advantage and organizational performance. Omega, 34(2), 107-124. https://doi:10.1016/j.omega.2004.08.002

Linton, J. D., Klassen, R., \& Jayaraman, V. (2007). Sustainable supply chains: An introduction. Journal of operations management, 25(6), 1075-1082. https://doi.org/10.1016/j.jom.2007.01.012

Lopes, C.M., Scavarda, A., Hofmeister, L.F., Thome, A.M.T. \& Vaccaro, G.L.R. (2017). An analysis of the interplay between organizational sustainability, knowledge management, and open innovation. Journal of Cleaner Production, 142, 476-488. https:// doi.org/10.1016/j.jclepro.2016.10.083

López-Gamero, M. D., Molina-Azorín, J. F., \& Claver-Cortés, E. (2009). The whole relationship between environmental variables and firm performance: Competitive advantage and firm resources as mediator variables. Journal of Environmental Management, 90(10), 3110-3121. https://doi.org/10.1016/j.jenvman.2009.05.007

Luthra, S., Govindan, K., Kannan, D., Mangla, S. K., \& Garg, C. P. (2017). An integrated framework for sustainable supplier selection and evaluation in supply chains. Journal of Cleaner Production, 140, 16861698. https://doi.org/10.1016/j.jclepro.2016.09.078

Mahmoudi, A., Javed, S.A., \& Mardani, A. (2021). Gresilient Supplier Selection through Fuzzy Ordinal Priority Approach: Decision-making in Post-COVID era. Operations Management Research. https://doi.org/10.1007/s12063-021-00178-z

Mani, V., Agrawal, R., \& Sharma, V. (2014). Supplier selection using social sustainability: AHP based approach in India. International Strategic Management Review, 2(2), 98-112. https://doi.org/10.1016/j.ism.2014.10.003

Marshall, D., McCarthy, L., McGrath, P., \& Claudy, M. (2015). Going above and beyond: how sustainability culture and entrepreneurial orientation drive social sustainability supply chain practice adoption. Supply Chain Management, 20(4), 434-454. https://doi.org/10.1108/SCM-08-2014-0267

Melnyk, S. A., Sroufe, R. P., \& Calantone, R. (2003). Assessing the impact of environmental management systems on corporate and environmental performance. Journal of operations management, 21(3), 329-351. https://doi.org/10.1016/S0272-6963(02)00109-2

Mitra, S., \& Datta, P. P. (2014). Adoption of green supply chain management practices and their impact on performance: an exploratory study of Indian manufacturing firms. International Journal of Production Research, 52(7), 2085-2107. https://doi.org/10.1080/00207543.2013.849014

Mol, A.P. \& Carter, N.T. (2006). China's environmental governance in transition. Environmental Politics, 15(2), 149-170.

Pagell, M. \& Wu, Z. (2009). Building a more complete theory of sustainable supply chain management using case studies of 10 exemplars. Journal of Supply Chain Management, 45(2), 37-56. https://doi.org/10.1111/j.1745-493X.2009.03162.x

Pagell, M., \& Gobeli, D. (2009). How plant managers' experiences and attitudes toward sustainability relate to operational performance. Production and Operations Management, 18(3), 278-299. https://doi.org/10.1111/j.1937-5956.2009.01050.x

Porter, M.E. \& Kramer, M. R. (2006). Strategy \& society: the link between competitive advantage and corporate social responsibility. Harvard Business Review, 84(12), 78-85 
Pullman, M. E., Maloni, M. J., \& Carter, C. R. (2009). Food for thought: social versus environmental sustainability practices and performance outcomes. Journal of Supply Chain Management, 45(4), 38-54. https://doi.org/10.1111/j.1745-493X.2009.03175.x

Rao, P., \& Holt, D. (2005). Do green supply chains lead to competitiveness and economic performance?. International Journal of Operations \& Production Management, 25(9), 898-916. https://doi.org/10.1108/01443570510613956

Rao, S., \& Goldsby, T. J. (2009). Supply chain risks: a review and typology. The International Journal of Logistics Management, 20(1), 97-123. https://doi.org/10.1108/09574090910954864

Schaltegger, S., \& Burritt, R. (2014). Measuring and managing sustainability performance of supply chains: Review and sustainability supply chain management framework. Supply Chain Management, 19(3), 232241. https://doi.org/10.1108/SCM-02-2014-0061

Shahzad, M., Qu, Y., Javed, S.A., Zafar, A. U., \& Rehman, S. U. (2020). Relation of Environment Sustainability to CSR and Green Innovation: A Case of Pakistani Manufacturing Industry. Journal of Cleaner Production, 253, 119938. https://doi.org/10.1016/j.jclepro.2019.119938

Spangenberg, J. H., Fuad-Luke, A., \& Blincoe, K. (2010). Design for Sustainability (DfS): the interface of sustainable production and consumption. Journal of Cleaner Production, 18(15), 1485-1493. https://doi.org/10.1016/j.jclepro.2010.06.002

Stock, J. R., \& Boyer, S. L. (2009). Developing a consensus definition of supply chain management: a qualitative study. International Journal of Physical Distribution \& Logistics Management, 39(8), 690-711. https://doi.org/10.1108/09600030910996323

Toloo, M., \& Nalchigar, S. (2011). A new DEA method for supplier selection in presence of both cardinal and ordinal data. Expert Systems with Applications, 38(12), 14726-14731. https://doi.org/10.1016/j.eswa.2011.05.008

Trapp, A. C., \& Sarkis, J. (2016). Identifying robust portfolios of suppliers: A sustainability selection and development perspective. Journal of Cleaner Production, 112, 2088-2100. https://doi.org/10.1016/j. jclepro.2014.09.062

Tsoulfas, G. T., \& Pappis, C. P. (2008). A model for supply chains environmental performance analysis and decision making. Journal of Cleaner Production, 16(15), 1647-1657. https://doi.org/10.1016/j.jclepro.2008.04.018

Vachon, S., \& Klassen, R. D. (2006). Green project partnership in the supply chain: the case of the package printing industry. Journal of Cleaner production, 14(6-7), 661-671. https://doi.org/10.1016/j.jclepro.2005.07.014

Vachon, S., \& Mao, Z. (2008). Linking supply chain strength to sustainable development: a country-level analysis. Journal of Cleaner Production, 16(15), 1552-1560. https://doi.org/10.1016/j.jclepro.2008.04.012

Viscusi, W. K. (1983). Risk by choice: Regulating health and safety in the workplace. Cambridge, MA: Harvard University Press.

Wang, J., Zhang, Y., \& Goh, M. (2018). Moderating the role of firm size in sustainable performance improvement through sustainable supply chain management. Sustainability, 10(5), 1654. https://doi.org/10.3390/su10051654

Weeratunge, R. D., \& Herath, R. (2017). The dimensions of green supply chain management practices. In: Proceedings of the 3rd World Conference on Supply Chain Management, 2, 123-132. https://doi.org/10.17501/wcosm.2017.2111

Wu, L., Subramanian, N., Abdulrahman, M. D., Liu, C., Lai, K. H., \& Pawar, K. S. (2015). The impact of integrated practices of lean, green, and social management systems on firm sustainability performance-evidence from Chinese fashion auto-parts suppliers. Sustainability, 7(4), 3838-3858. https://doi.org/10.3390/su7043838

Yang, C.L., Lin, S.P., Chan, Y.H. \& Sheu, C. (2010). Mediated effect of environmental management on manufacturing competitiveness: an empirical study. International Journal of Production Economics, 123(1), 210-220. https://doi.org/10.1016/j.ijpe.2009.08.017

Yang, M. G., Hong, P., \& Modi, S. B. (2011). Impact of Lean Manufacturing and Environmental Management on Business Performance: An Empirical Study of Manufacturing Firms. International Journal of Production Economics, 129, 251-261. https:/ / doi.org/10.1016/j.ijpe.2010.10.017

Zailani, S., Jeyaraman, K., Vengadasan, G. and Premkumar, R. (2012). Sustainable supply chain management (SSCM) in Malaysia: A survey. International Journal of Production Economics, 140(1), 330-340. https://doi.org/10.1016/j.ijpe.2012.02.008 
Zain, M. \& Kassim, N.M. (2012). The influence of the internal environment and continuous improvements on firms' competitiveness and performance. Procedia-Social and Behavioral Sciences, 65, 26-32. https://doi.org/10.1016/j.sbspro.2012.11.086

Zhu, Q. \& Sarkis, J. (2004). Relationships between operational practices and performance among early adopters of green supply chain management practices in Chinese manufacturing enterprises. Journal of Operations Management, 22(3), 265-289. https://doi.org/10.1016/j.jom.2004.01.005

Zhu, Q., Sarkis, J. \& Lai, K.H. (2007). Green supply chain management: pressures, practices, and performance within the Chinese automobile industry. Journal of Cleaner Production, 15(11-12), 10411052. https://doi.org/10.1016/j.jclepro.2006.05.021

Zhu, Q., Sarkis, J., Cordeiro, J.J. \& Lai, K.H. (2008). Firm-level correlates of emergent green supply chain management practices in the Chinese context. Omega, 36(4), 577-591. https://doi.org/10.1016/j.omega.2006.11.009 